\title{
Functional groups of woody species in riparian forest in the Brazilian semi-arid region: phenological and morphophysiological evidence
}

\author{
ÉRICA DAIANE MARQUES DA SILVA E TEODORO
}

Universidade Federal Rural de Pernambuco

ANA PAULA ALVES DA SILVA

Universidade Federal do Rio Grande do Norte

NIELSON DINIVAN DA SILVA BRITO

Universidade Federal de Vicosa

MARIA JESUS NOGUEIRA RODAL

Universidade Federal Rural de Pernambuco

RENATA AKEMI SHINOZAKI-MENDES

Universidade Federal Rural de Pernambuco

André Luiz Alves de Lima ( $\nabla$ andre.alima@ufrpe.br)

Universidade Federal Rural de Pernambuco https://orcid.org/0000-0003-4504-5774

\section{Research Article}

Keywords: Caatinga, functional types, leaf traits, phenology, water use, wood density.

Posted Date: February 15th, 2022

DOI: https://doi.org/10.21203/rs.3.rs-1162572/v1

License: (c) (i) This work is licensed under a Creative Commons Attribution 4.0 International License. Read Full License 


\section{Abstract}

Relationships between morphophysiological and phenological traits of functional groups of tree species from seasonally dry tropical environments are reasonably known. However, such information is scarce for riparian forests in semi-arid environments, especially regarding the representativeness of these groups in the community. This study aimed to evaluate the relationship of the morphofunctional characteristics of leaves and stem in the identification of functional groups and how these traits vary in these groups in a riparian forest in the Brazilian semi-arid region. Traits of leaf phenology (specific leaf area, leaf area, leaf thickness, and leaf dry matter content), wood density, and amount of saturated water in the stem and their association with soil water availability, relative air humidity, precipitation, temperature, photoperiod, and vapor pressure deficit were evaluated in 23 species. Cluster analysis showed three functional groups: deciduous low wood density species (9\%), deciduous high wood density species (48\%), and non-deciduous species, which included semideciduous (17\%) and evergreen species (26\%). Deciduousness was positively related to specific leaf area and negatively related to leaf dry matter and leaf area. Deciduous and semideciduous species $(55.1 \%$ and $7.5 \%$ of the individuals in the community, respectively) showed a strong dependence on abiotic factors linked to precipitation and temperature, while the evergreen species showed a strong dependence on the vapor pressure deficit to trigger their phenophases. It was evident that the studied functional traits influenced the leaf habit, which is essential to determine the abundance of functional groups of woody species from riparian forests in the semi-arid region.

\section{Introduction}

The phenology of seasonally dry environments is determined by the duration and intensity of seasonal drought (Kushwaha et al. 2011), being related to the environmental factors and morphophysiological traits of plants found in these regions, especially those related to water control, such as stem and leaf traits (Fu et al. 2012). Phenological patterns are strongly influenced by water use and conservation strategies, which in turn are controlled by the combination of the physiological and architectural traits of the plant (Butz et al. 2017), together favoring the formation of functional types (Lima et al. 2021). However, the complex interaction between phenology and morphofunctional traits is still little explored, especially in riverbank ecosystems (riparian forests) located in semi-arid regions, which are targets of strong anthropogenic pressure (Hughes and Rood 2003). In addition, the representativeness of functional groups in these forests is unknown.

In semi-arid regions, phenological patterns are highly influenced by precipitation (Amorim et al. 2009; Leite and Machado 2010; Singh and Kushwaha 2016) and soil water availability (Chaturvedi et al. 2011, 2013; Singh and Kushwaha 2016). However, studies have shown that besides being correlated with abiotic factors, the functional and morphological characteristics of plants are also correlated with their phenology, providing mechanisms that allow them to deal with strong seasonality (Reich and Borchert 1984; Borchert 1994; Borchert and Rivera 2001; Westoby et al. 2002; Poorter and Markesteijn 2008). These mechanisms of resistance to drought reflect on the use and control of water by plants, for example, regarding their ability to store or access soil water (Singhand Kushwaha 2016).

The interaction between these complex mechanisms allowed the emergence of different drought resistance strategies, which can be evaluated from functional traits. Deciduousness, for example, which allows the plant to avoid drought (Borchert 1994; Chaturvedi et al. 2013), is negatively related to leaf dry matter content and leaf area and positively related to specific leaf area (Poorter and Markesteijn 2008). Other features, such as deep roots, greater stomatal control, smaller leaf area (Slot and Poorter 2007) and specific leaf area, and greater leaf thickness also reduce water loss from plants (Chaturvedi et al. 2013). In addition to these characteristics, a low wood density allows the plant to store large amounts of water in its stem and thus avoid large variations in water potential in regions with low water availability (Lima et al. 2012). Therefore, the interaction between different plant water-use strategies, such as between stem (Chave et al. 2009) and leaf 
(Wright et al. 2004) functional traits, are essential to evaluate the phenological behavior of the species and, consequently, of the functional groups (Borchert 1994; Lima et al. 2012; Oliveira et al. 2015).

Functional groups, in turn, help to understand the functioning of ecosystems by simplifying their floristic complexity (Prentice et al. 1992) and to monitor the effects of global changes on community structure and ecosystem processes (Lavorel et al. 2007). In addition, since the seasonal variation in water availability in the plant is one of the determining factors affecting phenology (Borchert 1994), the use of functional groups allows testing how functionally equivalent species respond to water availability and also allows comparison with other similar forests (Lavorel et al. 2007). However, although some studies have identified general patterns of plant functional types, the available data represent only a part of the wide range of ecosystems found in nature (Castellanos-Castro and Newton 2015).

In seasonally dry tropical environments, for example, functional groups related to plant phenology and morphofunctional traits have been identified (Lima et al. 2012; Castellanos-Castroand Newton 2015; Oliveira et al. 2015; Lima et al. 2021). These studies evidenced the predominance of deciduous species with high wood density certainly due to the better hydraulic resistance provided by higher wood density, while evergreen and deciduous species with low wood density were less abundant. In this case, it is possible that the evergreens are more limited to microsites where they can develop the root system and access underground water (Sobrado and Cuenca 1979; Wright et al. 2021). However, there is little information on the influence of morphofunctional traits on the configuration of functional groups in riparian forests in seasonally dry environments due to deforestation and the almost complete suppression of these forests (Nilsson and Berggren 2000; Hughes and Rood 2003).

Most studies on the phenology of plants in riparian forests have focused only on the relationships between phenological patterns and climatic seasonality (Antunes and Ribeiro 1999; Funch et al. 2002; Gundnerson et al. 2012; Cascaes et al. 2013; Azevedo et al. 2014) and on the influence of abiotic variables on the behavior of these species, both in seasonally wet (Reys et al. 2005; Moungsrimuangdee et al. 2017) and seasonally dry environments (Funch et al. 2002; Silva et al. 2011). In these forests, phenology can show peaks of phenophases in the wet season, which presents high precipitation (Silva et al. 2011; Azevedo et al. 2014; Moungsrimuangdee et al. 2017), or during the dry season (Antunes and Ribeiro 1999; Azevedo et al. 2014). However, more specific approaches to the phenology of species found in riparian forests relating abiotic factors and aspects of functional ecology have been little explored (Morin et al. 2010; Pringle et al. 2011), although they are essential for a better understanding of the functioning of ecosystems.

This study aimed to evaluate the relationship of the morphofunctional characteristics of leaves and stem in the determination of the functional groups under conditions of a riparian environment, seeking to understand the possible mechanisms behind the patterns found. For this, we analyzed how abiotic factors influence the morphofunctional traits and the phenology of these groups. Due to the greater water availability in riparian forests even when located in the semiarid, we sought to find functional traits that may allow the maximization of the use of this resource. Thus, we hypothesized the predominance of species with high wood density, which can support higher levels of water stress, as well as with leaves presenting characteristics associated with greater longevity, such as smaller specific leaf area and higher biomass content. Therefore, we expected greater abundance of evergreen species. It is possible that deciduous species are also well represented in the community, although retaining their leaves for a longer period than in drier environments and presenting high values of specific leaf area and low values of leaf area, leaf thickness, and leaf dry matter content.

\section{Methods}

\section{Study area}


The study was carried out in a riparian forest located in the banks of the Boi Morto stream, Mata da Pimenteira State Park $\left(07^{\circ} 53^{\prime} 21^{\prime \prime}\right.$ and $07^{\circ} 57^{\prime} 36^{\prime \prime} S ; 38^{\circ} 18^{\prime} 42^{\prime \prime}$ and $\left.38^{\circ} 17^{\prime} 7^{\prime \prime} \mathrm{W}\right)$, municipality of Serra Talhada, Pernambuco State, Brazil (Silva and Almeida 2013). The vegetation in the park is mostly deciduous, thorny, and arboreal-shrubby, which is typical of the caatinga (Melo et al. 2013). The soils found in the park are cambisols associated with red-yellow podzolics, planosols, and solonetz, and the area is situated in an altitude ranging from 500 to 700 meters (Silva and Almeida 2013). In the riparian forest area, the vegetation has a larger size, greater diversity (A.P.A. Silva, unpublished data 2018), and longer leaf longevity. The climate of the region according to the Köppen system is classified as BSwh' (hot semi-arid), with average annual rainfall of $653.2 \mathrm{~mm}$ and average temperature of $26^{\circ} \mathrm{C}$ (Silva and Almeida 2013). The rainy season starts in December and extends until May, concentrating 69.5\% of the annual precipitation (Silva and Almeida 2013), although presenting great interannual variability (Sampaio 1995). Data of precipitation, relative air humidity, and average temperature were obtained from a meteorological station located $11 \mathrm{~km}$ away from the park through the Pernambuco Water and Climate Agency (www.apac.pe.gov.br/). The photoperiod was obtained from Lammi (2015). The study took place between June/2017 and November/2018, comprising the end of the 2017 rainy season, two dry seasons (August/2017 - January/2018 and May/2018 - November/2018), and the full wet season of 2018 (February/2018 April/2018).

During the first year of the study, the rainfall was $611.8 \mathrm{~mm}$, thus being slightly below the historical average, and there was no rainfall during the last six months of the study period. In addition, during the first year of study the mean temperature was $25.9{ }^{\circ} \mathrm{C}$, with a minimum of $21.6^{\circ} \mathrm{C}$ and a maximum of $29.1^{\circ} \mathrm{C}$; the average relative humidity was $61.95 \%$, with a minimum of $44 \%$ and a maximum of $78.5 \%$; the gravimetric soil water content ranged from $1.04-6.81 \%$; and the annual variation of the photoperiod was 55 minutes (Fig. 1). In this period, the vapor pressure deficit (VPD) ranged from $0.63 \mathrm{Kpa}$ to $2.24 \mathrm{Kpa}$, with an average of $1.33 \mathrm{Kpa}$. During the last semester of the study, the average temperature was $26.7^{\circ} \mathrm{C}$, with a minimum of $24.5^{\circ} \mathrm{C}$ and a maximum of $29.5^{\circ} \mathrm{C}$; the average relative humidity was $50.4 \%$, with a minimum of $42 \%$ and maximum of $59.6 \%$; the gravimetric soil water content ranged from $0.7-1.6 \%$; and the average VPD was 1.8 $\mathrm{Kpa}$, with a minimum of $1.3 \mathrm{Kpa}$ and a maximum of $2.4 \mathrm{Kpa}$. The annual variation of the photoperiod was 50 minutes (Fig. 1).

\section{Data collection and analysis}

\section{Phenology}

For phenological monitoring, a stretch of one kilometer of riparian forest on each side of the bank, with each stretch presenting a width of five meters (A.P.A. Silva, unpublished data 2018) were established as the experimental plots. In these areas, 23 species were selected, representing $64 \%$ of the total number of species species and corresponding to $89 \%$ of the total number of individuals in the community (APA Silva, unpublished data 2018). Out of these, nine adult individuals of each species with stem diameter at ground level $>3 \mathrm{~cm}$ were marked (Rodal et al. 2013), considering taller individuals with apparent canopies for better visualization. Phenological observations were carried out monthly for 18 months, between June 2017 and November 2018. Budding phenophases, leaf shedding (by observing yellow or brown leaves and when leaves were partially or totally lost by the individual) and proportion of leaves in the canopy (all leaves in the canopy) were observed. The intensity of phenological events was estimated according to Fournier (1974), with the intensity of the phenophases being quantified from zero to four for each individual (Fournier intensity index), where zero represents the absence of phenophase, one represents a phenophase between 1-25\%, two represents a phenophase between $26-50 \%$, three represents a phenophase between $51-75 \%$, and four represents a phenophase between $76-100 \%$. The phenophase intensity for each species is given through the formula: $\left(\sum\right.$ Fournier $\left./ 4 N\right)$ * 100 , where $\sum$ Fournier is the value of the Fournier index for each individual and $\mathrm{N}$ is the number of individuals of the species. The deciduousness of species was based on Williams et al. (1997), considering as evergreens the especies that remained with more than $50 \%$ of leaves in their canopy during the 12 months, as semi-deciduous the species that lose more than $50 \%$ of leaves in their 
canopy in the dry season, although not completely losing their leaves, and as deciduous the especies that lose their leaves during the dry season and remain leafless for at least a month.

\section{Wood density}

Wood density was determined from five individuals of each species through samples of the branch with at least three $\mathrm{cm}$ in diameter. The samples had their barks removed and then were immersed in water for five days for maximum saturation (Chave et al. 2009). After this period, the samples were removed and remained out of the water for 10 minutes to remove excess water. Subsequently, for measuring the displacement of liquid, each sample was immersed in another container with distilled water to determine their volume. Then, to measure dry matter, the samples were dried in an oven at a temperature of $103^{\circ} \mathrm{C}$ for 72 hours and weighed (Truguilho et al. 1990). Basic wood density was determined through the relationship between the dry matter of the sample and its saturated volume $\left(\mathrm{g} / \mathrm{cm}^{3}\right)$ (Pérez-Harguindeguy et al. 2013). The amount of saturated water in the stem (Qwsat. \%) was obtained by the formula: Qwsat = 100 (V-DM)/DM; where V is the displaced volume and DM the dry matter (Borchert 1994). Species were considered as having low wood density when presenting a density lower than $0.5 \mathrm{~g} / \mathrm{cm}^{3}$ and as having high wood density when presenting a density higher or equal to $0.5 \mathrm{~g} / \mathrm{cm}^{3}$ (Borchert 1994).

\section{Leaf traits}

The functional traits of leaf thickness, leaf area, specific leaf area, and leaf dry matter content were determined according to the protocol by Pérez-Harguindehuy et al. (2013), who recommended collecting ten leaves per individual in five individuals of each species. Leaf thickness was obtained using a stainless hardened digital caliper (MTX-316119). To obtain the leaf area $\left(\mathrm{mm}^{2}\right)$, each leaf was digitized using a flatbed scanner and their dimensions (not including the petiole) were determined using the software Image $\mathrm{J} \cap$. The specific leaf area was calculated using the ratio between the leaf area $\left(\mathrm{mm}^{2}\right)$ and the dry weight $(\mathrm{mg})$ obtained in an oven at $70^{\circ} \mathrm{C}$ for 72 hours. Leaf dry matter content was obtained by dividing the dry weight of each leaf by its wet weight $\left(\mathrm{mg} \cdot \mathrm{g}^{-1}\right)$.

\section{Soil water content}

Soil samples were collected monthly on the same collection dates used for phenological data. Collections were carried out at a depth of $20 \mathrm{~cm}$ using an auger at ten random points (five on each side of the banks). To avoid moisture loss, the samples were stored in closed plastic bags for subsequent weighing in the laboratory to obtain the wet weight and dry weight after drying in an oven at $105^{\circ} \mathrm{C}$ for 24 hours. The gravimetric soil water content was obtained through the equation: \% (G): (wet weight - dry weight) *100/ dry weight (Embrapa 1997).

\section{Statistical analysis}

For multivariate analysis, a data matrix was elaborated containing the species as descriptors and the phenological data and functional traits as objects. Box-Cox transformation was used with $\lambda=0.5$ (Box and Cox 1964). Then, a paired group with a Euclidean similarity measure was used as the method for linking the objects and the descriptors in a cluster. Then, the average value of the group was used, and non-metric multidimensional scaling (MDS) analysis was performed from the triangular matrix in order to identify the main groups to which the descriptors are ordered (Mardia et al. 1980).

After identifying the functional groups, principal component analysis (PCA) was performed including the functional traits, whose groups were compared using the ANOSIM test with 9999 permutations to verify which morphofunctional traits had the greatest influence on the separation of the functional groups. Subsequently, canonical correlation analysis (CCA) was performed with the phenological data of each functional and abiotic group for each vegetative phenophase (Clarke 1993), in order to identify which abiotic variables had the greatest influence on the triggering of phenophases.

\section{Results}


Out of the studied species, $57 \%$ were deciduous, $26 \%$ evergreens, and $17 \%$ semideciduous (Table 1 ). Thus, $43 \%$ of the species remained with their leaves throughout the year, although with different leaf fall intensities. Basic wood density $\left(W D \mathrm{~g} / \mathrm{cm}^{3}\right)$ and water storage capacity in the stem (Qwsat\%) varied between species and were inversely proportional $\left(\mathrm{r}^{2}=\right.$ 0.775 ) (Table 1). WD ranged from $0.28 \mathrm{~g} / \mathrm{cm}^{3}$, as recorded for Jatropha mollissima, to $0.81 \mathrm{~g} / \mathrm{cm}^{3}$, as observed for Libidibia ferrea, while the Qwsat ranged from 20.18-222.6\% of the dry weight (Table 1). 
Table 1

Functional traits of woody species of Mata da Pimenteira State Park, Serra Talhada - PE, Brazil, sorted according to the wood density, from June/2017 to November/2018.

\begin{tabular}{|c|c|c|c|c|c|c|c|c|}
\hline Specie & Family & $\begin{array}{l}\text { WD } \\
\left(\mathrm{g} / \mathrm{cm}^{3}\right)\end{array}$ & $\begin{array}{l}\text { QWsat } \\
\text { (\%) }\end{array}$ & $\begin{array}{l}\mathrm{LA} \\
\left(\mathrm{cm}^{2}\right)\end{array}$ & $\begin{array}{l}\text { SLA } \\
\left(\mathrm{cm}^{2} / \mathrm{g}\right)\end{array}$ & $\begin{array}{l}\text { LT } \\
(\mathrm{mm})\end{array}$ & $\begin{array}{l}\text { LDMC } \\
\text { (mg.g- } \\
\text { ') }\end{array}$ & Leaf fenology \\
\hline $\begin{array}{l}\text { Jatropha } \\
\text { molissima } \\
\text { (Pohl). Baill. }\end{array}$ & Euphorbiaceae & 0.28 & 222.59 & 144.47 & 142.99 & 0.34 & 0.17 & Deciduous \\
\hline $\begin{array}{l}\text { Manihot } \\
\text { carthaginensis } \\
\text { (Müll.Arg.) } \\
\text { Allem. }\end{array}$ & Euphorbiaceae & 0.33 & 194.14 & 306.18 & 158.34 & 0.19 & 0.24 & Deciduous \\
\hline $\begin{array}{l}\text { Triplaris } \\
\text { gardneriana } \\
\text { Wedd. }\end{array}$ & Polygonaceae & 0.46 & 117.26 & 65.58 & 172.43 & 0.25 & 0.43 & Evergreen \\
\hline $\begin{array}{l}\text { Mimosa } \\
\text { arenosa } \\
\text { (Willd.) Poir. }\end{array}$ & Fabaceae & 0.57 & 77.78 & 30.74 & 171.35 & 0.10 & 0.31 & Deciduous \\
\hline $\begin{array}{l}\text { Piptadenia } \\
\text { stipulacea } \\
\text { (Benth.) Ducke }\end{array}$ & Fabaceae & 0.60 & 20.18 & 35.69 & 198.25 & 0.10 & 0.33 & Deciduous \\
\hline $\begin{array}{l}\text { Licania rigida } \\
\text { Benth. }\end{array}$ & Chrysobalanaceae & 0.61 & 53.28 & 99.45 & 93.80 & 0.33 & 0.42 & Evergreen \\
\hline $\begin{array}{l}\text { Aspidosperma } \\
\text { pyrifolium } \\
\text { Mart. }\end{array}$ & Apocynaceae & 0.63 & 45.73 & 41.60 & 159.19 & 0.24 & 0.35 & Deciduous \\
\hline $\begin{array}{l}\text { Chloroleucon } \\
\text { dumosum } \\
\text { (Benth.) G.P. } \\
\text { Lewis }\end{array}$ & Fabaceae & 0.63 & 50.14 & 16.58 & 165.28 & 0.10 & 0.40 & Deciduous \\
\hline $\begin{array}{l}\text { Cynophalla } \\
\text { flexuosa L. J. } \\
\text { Presl }\end{array}$ & Capparaceae & 0.65 & 59.23 & 33.77 & 49.28 & 0.28 & 0.50 & Evergreen \\
\hline $\begin{array}{l}\text { Annona } \\
\text { leptopetala (R. } \\
\text { E. Fr.) H. Rainer }\end{array}$ & Annonaceae & 0.65 & 51.60 & 25.97 & 226.93 & 0.13 & 0.20 & Deciduous \\
\hline $\begin{array}{l}\text { Croton } \\
\text { blanchetianus } \\
\text { Baill. }\end{array}$ & Euphorbiaceae & 0.66 & 39.61 & 78.97 & 210.76 & 0.32 & 0.16 & Deciduous \\
\hline $\begin{array}{l}\text { Ziziphus } \\
\text { joazeiro Mart. }\end{array}$ & Rhamnaceae. & 0.67 & 48.01 & 29.76 & 174.36 & 0.16 & 0.33 & Evergreen \\
\hline $\begin{array}{l}\text { Schinopsis } \\
\text { brasiliensis } \\
\text { Engl. }\end{array}$ & Anacardiaceae & 0.67 & 52.97 & 16.05 & 244.57 & 0.10 & 0.29 & Semideciduous \\
\hline $\begin{array}{l}\text { Myracrodruon } \\
\text { urundeuva } \\
\text { Allemão }\end{array}$ & Anacardiaceae & 0.69 & 48.94 & 135.14 & 216.00 & 0.17 & 0.28 & Semideciduous \\
\hline $\begin{array}{l}\text { Sebastiania } \\
\text { macrocarpa } \\
\text { Mull. Arg. }\end{array}$ & Euphorbiaceae & 0.70 & 48.42 & 20.61 & 219.02 & 0.17 & 0.21 & Deciduous \\
\hline
\end{tabular}




\begin{tabular}{|c|c|c|c|c|c|c|c|c|}
\hline Specie & Family & $\begin{array}{l}\text { WD } \\
\left(\mathrm{g} / \mathrm{cm}^{3}\right)\end{array}$ & $\begin{array}{l}\text { QWsat } \\
(\%)\end{array}$ & $\begin{array}{l}\mathrm{LA} \\
\left(\mathrm{cm}^{2}\right)\end{array}$ & $\begin{array}{l}\text { SLA } \\
\left(\mathrm{cm}^{2} / \mathrm{g}\right)\end{array}$ & $\begin{array}{l}\text { LT } \\
(\mathrm{mm})\end{array}$ & $\begin{array}{l}\text { LDMC } \\
(\mathrm{mg} \cdot \mathrm{g}- \\
\text { 1) }\end{array}$ & Leaf fenology \\
\hline $\begin{array}{l}\text { Poecilanthe } \\
\text { grandiflora } \\
\text { Benth. }\end{array}$ & Fabaceae & 0.71 & 48.88 & 151.33 & 177.22 & 0.22 & 0.20 & Semideciduous \\
\hline $\begin{array}{l}\text { Cenostigma } \\
\text { pyramidale } \\
\text { (Tul.) Gagnon } \\
\text { \& G.P. Lewis }\end{array}$ & Fabaceae & 0.72 & 45.47 & 98.46 & 150.74 & 0.10 & 0.33 & Deciduous \\
\hline $\begin{array}{l}\text { Bauhinia } \\
\text { cheilantha } \\
\text { (Bong) Steud. }\end{array}$ & Fabaceae & 0.72 & 48.58 & 59.65 & 230.21 & 0.33 & 0.28 & Deciduous \\
\hline $\begin{array}{l}\text { Anadenanthera } \\
\text { colubrina } \\
\text { (Vell.) Brenan. }\end{array}$ & Fabaceae & 0.7450 & 37.20 & 35.46 & 115.39 & 0.10 & 0.53 & Deciduous \\
\hline $\begin{array}{l}\text { Colicodendron } \\
\text { yco (Cornejo) } \\
\text { Mart. \& Iltis }\end{array}$ & Capparaceae & 0.76 & 58.15 & 119.94 & 56.65 & 0.50 & 0.46 & Evergreen \\
\hline $\begin{array}{l}\text { Combretum } \\
\text { pisonioides } \\
\text { Taub. }\end{array}$ & Combretaceae & 0.78 & 39.74 & 12.72 & 237.63 & 0.13 & 0.28 & Deciduous \\
\hline $\begin{array}{l}\text { Parapiptadenia } \\
\text { zehntneri } \\
\text { (Harms) M. P. } \\
\text { Lima \& H. C. } \\
\text { Lima }\end{array}$ & Fabaceae & 0.80 & 36.72 & 88.37 & 153.46 & 0.10 & 0.39 & Evergreen \\
\hline $\begin{array}{l}\text { Libidibia ferrea } \\
\text { (Mart. Ex. Tull.) } \\
\text { L. P. Queiroz }\end{array}$ & Fabaceae & 0.81 & 42.09 & 45.57 & 92.13 & 0.10 & 0.32 & Semideciduous \\
\hline
\end{tabular}

Abbreviations: WD: wood density, QWsat: water storage capacity, LA: leaf area, SLA: specific leaf área, LT: leaf thickness, LDMC = leaf dry matter content.

Cluster analysis considering leaf functional traits, vegetative phenology, basic wood density, and water storage capacity in the stem showed the following three functional groups: deciduous species with low wood density (DLWD), deciduous species with high wood density (DHWD), and non-deciduous species. The latter group comprised semideciduous (SD) and evergreen (EG) species (Fig. 2). The formation of these groups was confirmed by the multidimensional scaling analysis (MDS) (Fig. 2).

The DLWD group included $9 \%$ of the studied species. These presented the highest values of leaf area (LA) and Qwsat and the lowest values of WD. The second group, DHWD, formed by deciduous species with high wood density, comprised $48 \%$ of the species, presenting the highest values of specific leaf area (SLA) and the lowest values of LA and Qwsat. The third group comprised $43 \%$ of the species and included semideciduous (17\%) and evergreen (26\%) species. The semideciduous species presented the highest values of WD and the lowest values of leaf thickness (LT), while the evergreen species presented the highest values of LT and leaf dry matter content (LDMC) and the lowest values of SLA.

Regarding the phenological behavior, the DLWD group sprouted before the first rains and started to shed leaves at the end of the rainy season, with the species remaining with less than $15 \%$ of their leaves for five months in the dry season. 
(Fig. 3). The DHWD group started budding with the first rains and leaf fall increased early in the dry season. However, this group remained with less than $15 \%$ of their leaves only during the last two months of this season (Fig. 3 ). In the third group, the semideciduous species also started budding with the first rains, although the peak of leaf fall occurred at the height of the dry season, just before the wet season. (Fig. 3). On the other hand, evergreen species exchanged leaves constantly, with budding and leaf fall occurring simultaneously throughout the year (Fig. 3).

According to the result obtained by PCA (Fig. 4), it can be observed that the variables that most influenced the species were LA, Qwsat, WD (main component 1 - PC1), and SLA (main component 2 - PC2), respectively. That is, the leaf and wood functional traits had a greater influence on the distribution of species in the PCA than phenological traits. In addition, it can be stated that species that were close in distribution were similarly influenced by such variables. PC1 explained $57.7 \%$ of the group variation and PC2 explained $28.8 \%$.

The canonical correspondence analysis (CCA) (Fig. 5) demonstrated with significative difference $(p<0.001)$ for all analysis that budding in the DLWD group was mainly correlated to increased photoperiod, temperature, and vapor pressure deficit (VPD). In the DHWD and SD groups, the increase in relative air humidity, soil moisture, and precipitation served as a trigger for this phenophase. Budding in EG was shown to be inversely related to VPD.

The increase in photoperiod, temperature, and VPD was positively related to leaf fall for the DLWD and SD groups. The conservation of the canopy of evergreen species was also related to those variables (Fig. 5). In DHWD species, the maintenance of leaves in the canopy was mainly influenced by the increase in relative air humidity, soil moisture, and precipitation, while leaf fall was mainly triggered by the decrease in these variables (Fig. 5).

\section{Discussion}

As expected, the analyzed functional characteristics were good predictors for the determination of functional groups in the riparian forest studied, demonstrating that the traits of leaf area, wood density, amount of water in the stem, and specific leaf area are important for the phenological characterization and functional composition of these forests. This can be observed by the proximity of species in the distribution of PCA, suggesting that functional traits had similar effects on these species and demonstrating the strong influence of morphofunctional traits in the formation of groups. The identification of these groups allows a better understanding of the responses of plant species to environmental variability (Reich et al. 2003), including with regard to water availability, since the morphofunctional traits coordinated the phenological behavior of the groups, showing the water use and conservation strategies of riparian forest species in a semi-arid environment.

The functional groups determined in this study were similar to those determined in other areas of the semi-arid region (Lima et al. 2012; Oliveira et al. 2015, Wright et al. 2021). However, their representation in the studied community was different, suggesting that the greater availability and use of water in riparian forests influence the abundance of the morphological and phenological traits of leaves. It was found that $57 \%$ of the studied species were deciduous, an expected pattern for plants from seasonally dry environments (Méndez-Alonzo et al. 2013). However, among the deciduous species, only two presented low wood density, representing only $2.6 \%$ of the trees in the community (A.P.A. SILVA, personal communication 2018). These results indicate that the water greater availability favors plants with high wood density, which are structurally more representative, comprising $52.5 \%$ of the tree community (A.P.A. SILVA, personal communication 2018). On the other hand, $43 \%$ of the species (35.7\% of the individuals in the community) remained with their leaves both in the wet and in the dry season, demonstrating that the lack of rainfall during the dry period did not interfere as strongly in the deciduousness of these species (Antunes and Ribeiro 1999). This behavior suggests that these plants obtain water from the soil through their deeper root system (Borchert et al. 1994; Poorter and Markesteijn 2008; Wright et a. 2021) or from water storage in their roots (Jackson et al. 2007), as well as suggesting that these plants are efficient in stomatal control (Figueiredo-Lima et al. 2018). It is possible that these mechanisms can explain the 
phenological behavior regardless of precipitation and soil moisture, as has been reported for other riparian forests (Funch et al. 2002; Silva et al. 2011).

Regarding the three functional groups identified, the DLWD group, consisting of a minority of species, started budding before the rainy season, when there was an increase in the photoperiod (Galvão et al. 2021), as has been recorded in other seasonally dry environments (Rivera et al. 2002; Kushwaha et al. 2011; Lima et al. 2012; Oliveira et al. 2015; Lima et al. 2021). This behavior can be considered a strategy to anticipate the growth period, maximizing the production of photosynthates (Rivera et al. 2002). The literature reports that this phenological pattern is caused by the large amount of water that these species store in their stems (Borchert 1994; Borchert and Rivera 2001; Lima and Rodal 2010; Lima et al. 2012), which is used for the subsequent production of flowers and fruits (Rivera et al. 2002). In addition, the high leaf area index of these species allows a greater amount of light energy, maximizing assimilation in the short period when the species remains with leaves (Rivera et al. 2002). Furthermore, since DLWD present a lower investment in wall material for the cell wall structure, their hydraulic system becomes more vulnerable to collapse when exposed to stressful conditions (Hacke et al. 2001). Thus, these species avoid drought by shedding their leaves at the end of the rainy season, remaining well hydrated and with high values of water potential throughout the year (Borchertand Rivera 2001; Hacke et al. 2001).

Deciduous species with high wood density, which corresponded to $48 \%$ of the total, were highly dependant on precipitation, soil water availability, and relative air humidity to trigger their phenophases for presenting low water storage capacity in their stems, which is similar to what is reported in the literature (Borchert 1994; Lima and Rodal 2010; Lima et al. 2012; Wright et al. 2021). The leaves of these species fall at the beginning of the dry season as a strategy to avoid water loss (Borchert 1994; Wright et al. 2021). This strategy reflects an inverse relationship between SLA and leaf longevity, given that deciduous species present short-lived leaves (Pérez-Harguindeguy et al. 2013). The high values of specific leaf area also represent an important factor for the development and maintenance of these species, since they remain with leaves only for a short period of time and higher values of SLA tend to positively increase the photosynthetic rate (Pérez-Harguindeguy et al. 2013).

The high percentage of non-deciduous species (43\%), including semideciduous and evergreen species, and the fact that they remained with leaves in both the dry and rainy seasons, may be related to greater water availability in the riparian environment, which creates a milder microclimate (Azevedo et al. 2014), together with the high water holding capacity of the soil and the greater resistance of the tissues of the stems and leaves. These species presented higher values of wood density, and it is known that this trait favors a hydraulic structure that is more resistant to large variations in water potential during the dry season, allowing higher tensions in the xylem water column and minimizing possible damage to the hydraulic system, such as embolism (Hacke et al. 2001, Wright et al. 2021).

The evergreen species showed a stronger relationship with VPD for triggering their phenophases when compared to precipitation. This fact may be related to greater hydraulic safety due to greater stomatal control and a more efficient use of water, reducing transpiration during the dry season (Poorter and Markesteijn 2008; Markesteijn and Poorter 2009; Souza et al. 2020, Wright et al. 2021). The higher values of LT and LDMC and lower values of SLA characterize more resistant leaves and with greater control of stomatal conductance (Holbrook et al. 1995). The reinforced leaf structure allows for strong water control and consequent canopy maintenance during the dry season, preventing cavitation and damage to the plant hydraulic system (Markesteijn and Poorter 2009). These traits are associated with greater leaf mechanical strength and sunnier and drier environments, as well as longer-lasting leaves (Pérez-Harguindeguy et al. 2013). Leaves with high values of LDMC are relatively harder and more resistant to physical damage by wind (PérezHarguindeguy et al. 2013), as well as tending to be less palatable, decreasing the rate of predation by herbivores (Pringle et al. 2011).

The semideciduous species, for example, although remaining with leaves in both seasons, still showed a strong dependence of their phenology on abiotic factors related to precipitation and temperature, showing a greater intensity of

Page $10 / 20$ 
leaf fall at the height of the dry season. It is likely that these species have a better ability to explore soil water, given that they have higher values wood density, thus being more resistant to cavitation under water stress conditions than other functional types (Hacke et al. 2001; Reich et al. 2003; Chave et al., 2009). This dependence is evident when observing that these species can show different phenological behaviors according to the water availability of the environment (Hulshof et al. 2014), as is the case of the species Libidibia ferrea, Myracrodruon urundeuva (Lima et al. 2012; Souza et al. 2015), and Schinopsis brasiliensis, which can show deciduous behavior (Lima and Rodal 2010) or even evergreen (Barbosa et al. 1989).

Thus, it can be concluded that the functional groups determined in this study are similar to those found in other areas of seasonally dry environments, although the abundance of species that make up each group varies according to the water availability of the location. As an example, the influence of VPD on evergreen species is highlighted, while precipitation and soil moisture act on deciduous and semideciduous species. The set of wood and leaf morphofunctional traits were essential to explain the phenological behavior of each functional group, as well as the specificity of each group regarding environmental variables. As predicted, there was a predominance of species with high wood density, which is an important attribute for a more efficient exploration of soil water, minimizing damage to the hydraulic system (Hacke et al. 2001; Wright et al. 2021). The prevalence of this functional trait seems to optimize the presence of these species in the riparian environment in the semi-arid to the detriment of species in the low wood density group, which was represented by only two species, a much lower value than that observed in other seasonally dry environments (Lima et al. 2012; Oliveira et al. 2015). This is corroborated by the greater abundance of evergreen and semideciduous species, which presented higher values of wood density and structurally more resistant leaves. It can also be stated that although the studied forest is located in a seasonally dry environment, almost half of the species had their phenology influenced by environmental factors inherent to the riparian environment. Thus, it can be concluded that the morphofunctional and phenological characteristics of woody species from riparian forests are strong indicators of functional groups and should be considered in forest restoration plans.

\section{Declarations}

\section{Acknowledgements}

To the Fundação de Amparo à Ciência e Tecnologia de Pernambuco (FACEPE) for the financial support through the postgraduate scholarship (process IBPG-0914-2.03/16).

\section{Funding}

The research was supported with funding from the Fundação de Amparo à Ciência e Tecnologia de Pernambuco (FACEPE) through a postgraduate scholarship (process IBPG-0914-2.03/16).

\section{Data availability}

The datasets generated and analyzed during the current study are available from the corresponding author onreasonable request.

\section{Competing interest}

The authors declare no conflicts of interest.

\section{Autor Contributions}

All authors contributed to the study conception and design. Material preparation, data collection and analysis were performed by Érica Daiane Marques da Silva e Teodoro, André Luiz Alves de Lima, Ana Paula Alves da Silva, Maria Jesus 
Nogueira Rodal, Nielson Dinivan da Silva Brito and Renata Akemi Shinozaki-Mendes. The first draft of the manuscript was written by Érica Daiane Marques da Silva e Teodoro and all authors commented on previous versions of the manuscript. All authors read and approved the final manuscript.

\section{References}

1. Amorim IL, Sampaio EVSB, Araújo EL (2009) Fenologia de espécies lenhosas da caatinga do Seridó. RN Revista Árvore 33:491-499. https://doi.org/10.1590/S0100-67622009000300011

2. Antunes NB, Ribeiro JF (1999) Aspectos fenológicos de seis espécies vegetais em matas de galeria do Distrito Federal. Pesquisa Agropecuária Brasileira 34:1517-1527. https://doi.org/10.1590/S0100-204X1999000900001

3. Azevedo IFP, Nunes YRF, Ávila MA, Silva DL, Fernandes GW, Veloso RB (2014) Phenology of riparian tree species in a transitional region in southeastern Brazil. Brazilian. Journal of Botany 37:47-59. https://doi.org/10.1007/s40415014-0046-5

4. Barbosa DCA, Alves JLH, Prazeres SM, Paiva AMA (1989) Dados fenológicos de 10 espécies arbóreas de uma área de caatinga. (Alagoinha- PE) Acta Botanica Brasilica 3:109-117. https://doi.org/10.1590/S010233061989000300011

5. Borchert R (1994) Soil and stem water storage determine phenology and distribution of tropical dry forest trees. Ecology 75:1437-1449. https://doi.org/10.2307/1937467

6. Borchert R, Rivera G (2001) Photoperiodic control of seasonal development and dormancy in tropical stem-succulent. trees Tree Physiology 21:213-221. https://doi.org/10.1093/treephys/21.4.213

7. Box GEP, Cox DR (1964) An analysis of transformations. Journal of the Royal Statistical Society Series B 26:211252. https://doi.org/10.1111/j.2517-6161.1964.tb00553.x

8. Bullock SH, Mooney HA, Medina E (1995) Seasonally Dry Tropical Forest. Cambridge University Press, Cambridge. https://doi.org/10.1017/CB09780511753398

9. Butz P, Raffelsbauer V, Graefe S, Peters T, Cueva E, Holscher D, Brauning A (2017) Tree responses to moisture fluctuations in a neotropical dry forest as potential climate change indicators. Ecol Ind 83:559-571. https://doi.org/10.1016/j.ecolind.2016.11.021

10. Carvalho FS, Sartori ALB (2015) Reproductive phenology and seed dispersal syndromes of woody species in the Brazilian Chaco. J Veg Sci 26:302-311. https://doi.org/10.1111/jvs.12227

11. Cascaes MF, Citadini-Zanete, Harter-Marques B (2013) Reproductive phenology in a riparian rainforest in the south of Santa Catarina state, Brazil. Anais da Academia Brasileira de Ciências 85:1449-1460. https://doi.org/10.1590/000137652013105112

12. Castellanos- Castro C, Newton AC (2015) Leaf and stem trait variation and plant functional types in 113 woody species of a seasonally dry tropical forest. Colombia Forestal 18:117-138.

https://doi.org/10.14483/udistrital.jour.colomb.for.2015.1.a07

13. Chaturvedi RK, Raghubanshi AS, Singh JS (2011) Plant functional traits with particular reference to tropical deciduous forests: A review. J Biosci 36:963-981. https://doi.org/10.1007/s12038-011-9159-1

14. Chaturvedi RK, Raghubanshi AS, Singh JS (2013) Growth of tree seedlings in a tropical dry forest in relation to soil moisture and leaf traits. Journal of Plant Ecology 6:158-170. https://doi.org/10.1093/jpe/rts025

15. Chave J, Coomes D, Jansen S, Lewis SL, Swenson NG, Zanne AE (2009) Towards a worldwide wood economics spectrum. Ecol Lett 12:351-366. http://https//doi.org/10.1111/j.1461-0248.2009.01285.x

16. Cianciaruso MV, Silva IA, Manica LT, Souza JP (2013) Leaf habit does not predict leaf functional traits in cerrado woody species. Basic Appl Ecol 14:404-412. https://doi.org/10.1016/j.baae.2013.05.002 
17. Clarke KR (1993) Non-parametric multivariate analyses of changes in community structure. Austral Ecol 18:117-143. https://doi.org/10.1111/j.1442-9993.1993.tb00438.x

18. Empresa Brasileira de Pesquisa Agropecuária (1997) Sistema brasileiro de classificação dos solos. Rio de Janeiro

19. Figueiredo-Lima KV, Falcão HM, Melo-de-Pinna GF, Albacete A, DODD IC, Lima AL, Santos MG (2018) Leaf phytohormone levels and stomatal control in an evergreen woody species under semiarid environment in a Brazilian seasonally dry tropical forest. Plant Growth Regul 85:437-445. https://doi.org/10.1007/s10725-018-0405-5

20. Fournier LA (1974) Un Método Cuantitativo para la Medición de Características Fenológicas en Árboles. Revista Turrialba 24:422-423

21. Fu P, Jiang Y, Wang A, Brodribb TJ, Zhang J, Zhu S, Cao K (2012) Stem hydraulic traits and leaf water-stress tolerance are co-ordinated with the leaf phenology of angiosperm trees in an Asian tropical dry karst forest. Ann Botany 110:189-199. https://doi.org/10.1093/aob/mcs092

22. Funch LS, Funch R, Barroso GM (2002) Phenology of Gallery and Montane Forest in the Chapada Diamantina, Bahia, Brazil. Biotropica 34:40-50. https://doi.org/10.1111/j.1744-7429.2002.tb00240.x

23. Galvão FG, Lima ALA, Oliveira CC, Silva VF, Rodal MJN (2021) The importance of wood density in determining the phenology of tree species in a coastal rain forest. Biotropica 53:1134-1141. https://doi.org/10.1111/btp.12954

24. Gunderson CA, Edwards NT, Walker AV, O'Hara KH, Campion CM, Hanson PJ (2012) Forest phenology and a warmer climate - growing season extension in relation to climatic provenance. Glob Change Biol 18:2008-2025. https://doi.org/10.1111/j.1365-2486.2011.02632.x

25. Hacke UG, Sperry JS, Pockman WT, Davis SD, Mcculloh KA (2001) Trends in wood density and structure are linked to prevention of xylem implosion by negative pressure. Oecologia 126:457-461.

https://doi.org/10.1007/s004420100628

26. Hughes FMR, Rood SB (2003) Allocation of river flows for restoration of foodplain forest ecosystems: A review of approaches and their applicability in Europe. Environ Manage 32:12-33. https://doi.org/10.1007/s00267-003-2834-8

27. Hulshof CM, Martínez-Yrízar A, Burquez A, Boyle B, Enquist BJ (2014) Plant functional trait variation in tropical dry forests: a review and synthesis.. In: In: Sánchez-Azofeifa A, Powers JS, Fernandes GW, Quesada M (eds) Tropical dry forests in the Americas: ecology, conservation, and management. CRC Press, Boca Raton, FL, US, pp 129-140. https://doi.org/10.1201/b15417

28. Jackson RB, Pockman WT, Hoffmann WA, Bleby TM, Armas C (2007) Structure and function of root systems.. In: In: Pugnaire FI, Valladares F (eds) Functional Plant Ecology, 2- edn. ed. CRC Press, USA, pp 151-173

29. Kushwaha CP, Tripathi SK, Tripathi BD, Singh KP (2011) Patterns of tree phenological diversity in dry tropics. Acta Ecol Sin 31:179-185. https://doi.org/10.1016/j.chnaes.2011.04.003

30. Lammi J (2015) Online photoperiod calculator. http://http://www.sci.fi/ benefon/sol.html. Acessado em 20 de junho de 2018

31. Leite AVL, Machado IC (2010) Reproductive biology of woody species in Caatinga, a dry forest of northeastern Brazil. J Arid Environ 74:1374-1380. https://doi.org/10.1016/j.jaridenv.2010.05.029

32. Lima ALA, Rodal MJN (2010) Phenology and wood density of plants growing in the semi-arid region of northeastern Brazil. J Arid Environ 74:1363-1373. https://doi.org/10.1016/j.jaridenv.2010.05.009

33. Lima ALA, Sampaio EVSB, Castro CC, Rodal MJN, Antonino ACD, Melo AL (2012) The phenology and functional stem attributes of woody species allow for the identification of functional groups in the semiarid region of. Brazil Trees 26:1605-1616. https://doi.org/10.1007/s00468-012-0735-2

34. Lima ALA, Rodal MJN, Castro CC, Antonino ACD, Melo ALde, Gonçalves-Souza T, Sampaio EVSB (2021) Phenology of high- and low-density wood deciduous species responds differently to water supply in tropical semiarid regions. J Arid Environ 193. https://doi.org/10.1016/j.jaridenv.2021.104594

Page $13 / 20$ 
35. Mardia KV, Kent JT, Bibby JM (1980) Multivariate Analysis. Academic Press pp. 521

36. Markesteijn L, Poorter L (2009) Seedling root morphology and biomass allocation of 62 tropical tree species in relation to drought- and shade-tolerance. J Ecol 97:311-325. https://doi.org/10.1111/j.1365-2745.2008.01466.x

37. Matheny AM, Mirfenderesgi G, Bohrer G (2017) Trait-based representation of hydrological functional properties of plants in weather and ecosystem models. Plant Diversity 39:1-12. https://doi.org/10.1016/j.pld.2016.10.001

38. Melo AL, Lima ALA, Menezes TGC, Cordeiro RS, Santos ES, Farias SGG, Silva FV, Caldas DRM, Matis SS, Melo R, Lima LR, Cordeiro WPFS, Gomes APS, Rodal MJN (2013) Flora vascular terrestre. In: Santos EM, Melo Júnior M, SilvaCavalcanti, JS, Almeida GVL (ed). Parque Estadual Mata da Pimenteira: Riqueza Natural e Conservação da Caatinga. Edufrpe, Recife pp. 83-103

39. Méndez-Alonzo R, Pineda-García F, Paz H, Rosell J, Olson ME (2013) Leaf phenology is associated with soil water availability and xylem traits in a tropical dry forest. Trees 27:745-754. https://doi.org/10.1007/s00468-012-0829-x

40. Morin X, Roy J, Sonié L, Chuine I (2010) Changes in leaf phenology of three European oak species in response to experimental climate change. New Phytol 186:900-910. https://doi.org/10.1111/j.1469-8137.2010.03252.x

41. Moungsrimuangdee B, Waiboonya P, Larpkern P, Yodsa-Nga P, Saeyamg M (2017) Reproductive phenology and growth of riparian species along Phra Prong river, sa Kaeo Province. eastern Thailand Journal of Landscape Ecology 10:35-48. https://doi.org/10.1515/jlecol-2017-0003

42. Neves SPS, De Miranda LP, Rossatto DR, Funch LS (2017) The roles of rainfall, soil properties, and species traits in flowering phenology along a savanna-seasonally dry tropical forest gradiente. Brazilian Journal of Botany 40:665679. https://doi.org/10.1007/s40415-017-0368-1

43. Nilsson C, Berggren K (2000) Alterations of riparian ecosystems caused by river regulation. BioScience 50: 783-792. https://doi.org/10.1641/0006-3568(2000)050[0783:AORECB]2.0.CO;2

44. Oliveira CC, Zandavalli RB, Lima ALA, Rodal MJN (2015) Functional groups of woody species in semi-arid regions at low latitudes. Austral Ecol 40:40-49. https://doi.org/10.1111/aec.12165

45. Pérez-Harguindeguy N, Díaz S, Garnier E, Lavorel S, Poorter H, Jaureguiberry P, Bret-Harte MS, Cornwell WK, Craine M, Gurvich DE, Urcelay C, Veneklaas EJ, Reich PB, Poorter L, Wright IJ, Ray P, Enrico L, Pausas JG, De Vos AC, Buchmann N, Funes G, Quétier F, Hodgson JG, Thompson K, Morgan HD, Ter Steege H, Van Der Heijden MGA, Sack L, Bloder B, Poschlod P, Vaieretti MV, Conti G, Staver AC, Aquino S, Cornelissen JHC (2013) New handbook for standardised measurement of plant functional traits worldwide. Aust J Bot 61:167-234. https://doi.org/10.1071/BT12225

46. Poorter L, Markesteijn L (2008) Seedling traits determine drought tolerance of tropical tree species. Biotropica 40:321-331. https://doi.org/10.1111/j.1744-7429.2007.00380.x

47. Pringle EG, Adams RI, Broadbent E, Busby PE, Donatti Cl, Kurten EL, Renton K, Dirzo R (2011) Distinct leaf-trait syndromes of evergreen and deciduous trees in a Seasonally Dry Tropical Forest. Biotropica 43:299-308. https://doi.org/10.1111/j.1744-7429.2010.00697.x

48. Reich PB, Borchert R (1984) Water Stress and Tree Phenology in a Tropical Dry Forest in the Lowlands of Costa Rica. J Ecol 72:61-74. https://doi.org/10.2307/2260006

49. Reich PB, Wright IJ, Cavender-Bares J, Craine JM, Oleksyn J, Westoby M, Walters MB (2003) The evolution of plant functional variation: traits, spectra, and strategies. Int J Plant Sci 164:143-164. https://doi.org/10.1086/374368

50. Reys P, Galetti M, Morellato LPC, Sabino J (2005) Fenologia reprodutiva e disponibilidade de frutos de espécies arbóreas em Mata Ciliar no Rio Formoso, Mato Grosso do Sul. Biota Neotrop 5. https://doi.org/10.1590/S167606032005000300021

51. Ringrose S (2003) Characterisation ofriparian woodlands and their potential water loss in the distal Okavango Delta, Botswana. Appl Geogr 23:281-302. https://doi.org/10.1016/j.apgeog.2003.08.006 
52. Rivera G, Elliott S, Guillermo LS, Nicolossi G, Coradin VTR, Borchert R (2002) Increasing day-length induces spring flushing of tropical dry forest trees in the absence of rain. Trees 16:445-456. https://doi.org/10.1007/s00468-0020185-3

53. Rodal MJN, Sampaio EVSB, Figueiredo MA (2013) Manual sobre métodos de estudo florístico e fitossociológico: ecossistema caatinga. Sociedade Botânica do Brasil, Brasília

54. Sampaio EVSB (1995) Overview of the Brazilian Caatinga.. In: In: Bullock SH, Mooney HA, Medina E (eds) Seasonally dry tropical forests. Cambridge University Press, Cambridge, pp 35-63.

https://doi.org/10.1017/CB09780511753398.003

55. Silva TGF, Almeida AQ (2013) Climatologia e Características Geomorfológicas.. In: In: Santos EM, Melo-Júnior M, Silva-Cavalcanti JS, Almeida GVL (eds) Parque Estadual Mata da Pimenteira: Riqueza Natural e Conservação da Caatinga. Editora Universitária da UFRPE, Recife, pp 30-37

56. Silva IA, Silva DM, Carvalho GH, Batalha MA (2011) Reproductive phenology of Brazilian savannas and riparian forests: environmental and phylogenetic issues. Ann For Sci 68:1207-1215. https://doi.org/10.1007/s13595-0110071-5

57. Singh KP, Kushwaha CP (2016) Deciduousness in tropical trees and its potential as indicator of climate change: A review. Ecol Ind 69:699-706. https://doi.org/10.1016/j.ecolind.2016.04.011

58. Slot M, Poorter L (2007) Diversity of tropical tree seedling responses to drought. Biotropica 39:683-690. https://doi.org/10.1111/j.1744-7429.2007.00328.x

59. Sobrado MA, Cuenca G (1979) Aspectos del uso de agua de especies deciduas y siempreverdes en un bosque seco tropical de Venezuela. Acta Científica Venezolana 30:302-308

60. Souza CB, Oliveira RS, Araújo FS, Lima ALA, Rodal MJN (2015) Divergências funcionais e estratégias de resistência à seca entre espécies decíduas e sempre verdes tropicais. Rodriguésia 66:21-32. https://doi.org/10.1590/21757860201566102

61. Souza BC, Carvalho ECD, Oliveira RS, Araújo FS, Lima ALA, Rodal MJNR (2020) Drought response strategies of deciduous and evergreen woody species in a seasonally dry neotropical forest. Oecologia 194:221-236. https://doi.org/10.1890/03-4022

62. Staggemeier VG, Diniz-Filho JAF, Morellato LPC (2010) The shared influence of phylogeny and ecology on the reproductive patterns of Myrteae (Myrtaceae). J Ecol 98:1409-1421. https://doi.org/10.1111/j.13652745.2010.01717.x

63. Trugilho PF, Silva DA, Frazão FJL, Matos JLM (1990) Comparação de métodos de determinação da densidade básica em madeira. Acta Amazonica 20:307-319. https://doi.org/10.1590/1809-43921990201319

64. Westoby M, Falster DS, Moles AT, Vesk PA, Wright IJ (2002) Plant Ecological Strategies: Some Leading Dimensions of Variation Between Species. Annu Rev Ecol Syst 33:125-159.

https://doi.org/10.1146/annurev.ecolsys.33.010802.150452

65. Williams RJ, Myers BA, Muller WJ, Duff GA, Eamus D (1997) Leaf Phenology of Woody Species in a North Australian Tropical Savanna. Ecological Society of America 78:2542-2558. https://doi.org/10.2307/2265913v

66. Wright CL, Lima ALA, Souza ES, West JB, Wilcox BP (2021) Plant functional types broadly describe water use strategies in the Caatinga, a seasonally dry tropical forest in northeast Brazil. Ecology and Evolution 00:1-18. https://doi.org/10.1002/ece3.7949

67. Wright IJ, Leishman MR, Read C, Westoby M (2006) Gradients of light availability and leaf traits with leaf age and canopy position in 28 Australian shrubs and trees. Funct Plant Biol 33:407-419. https://doi.org/10.1071/FP05319

\section{Figures}



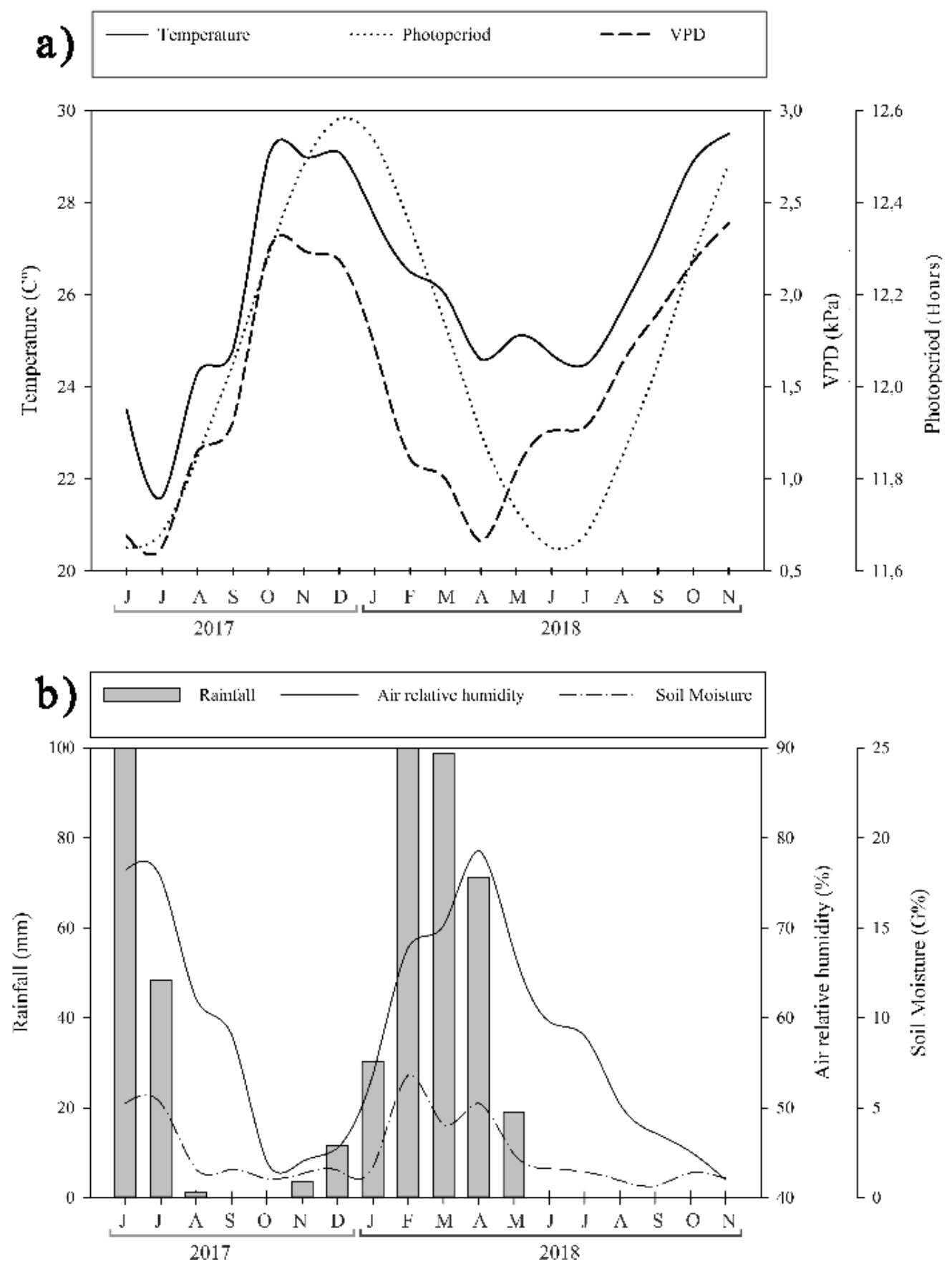

Figure 1

Monthly abiotic data of Mata da Pimenteira State Park, Serra Talhada, PE, Brazil. VPD: Vapor pressure deficit. 

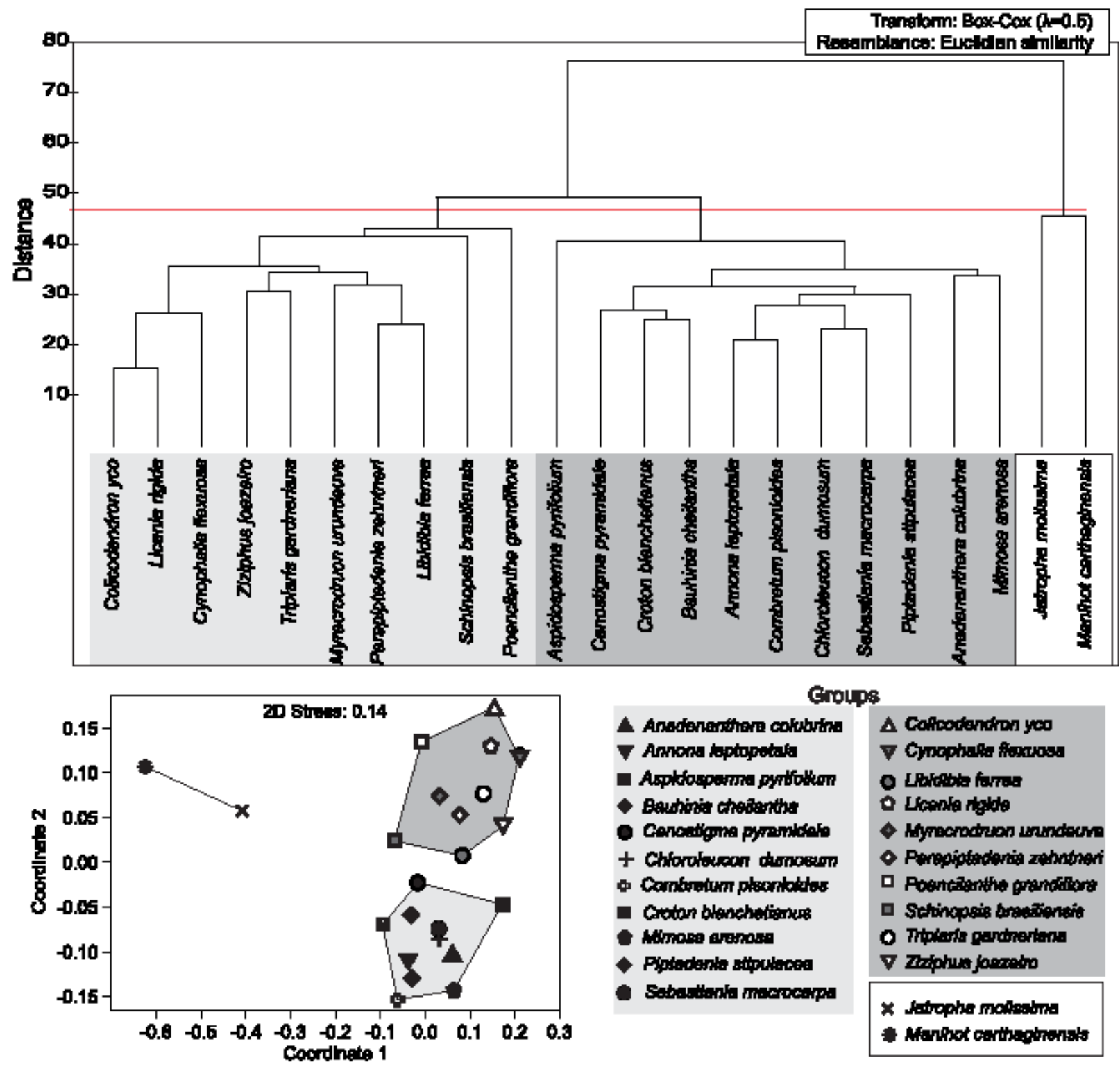

Figure 2

A. Cluster analysis; and B. Multidimensional scaling analysis (MDS) of the functional traits of woody species from a riparian forest area in the caatinga, Serra Talhada, Pernambuco, Brazil, between June/2017 and November/2018. Dark gray: non-deciduous species (evergreens and semi-deciduous); light gray: deciduous species with high wood density; white: deciduous species with low wood density. 
DLWD
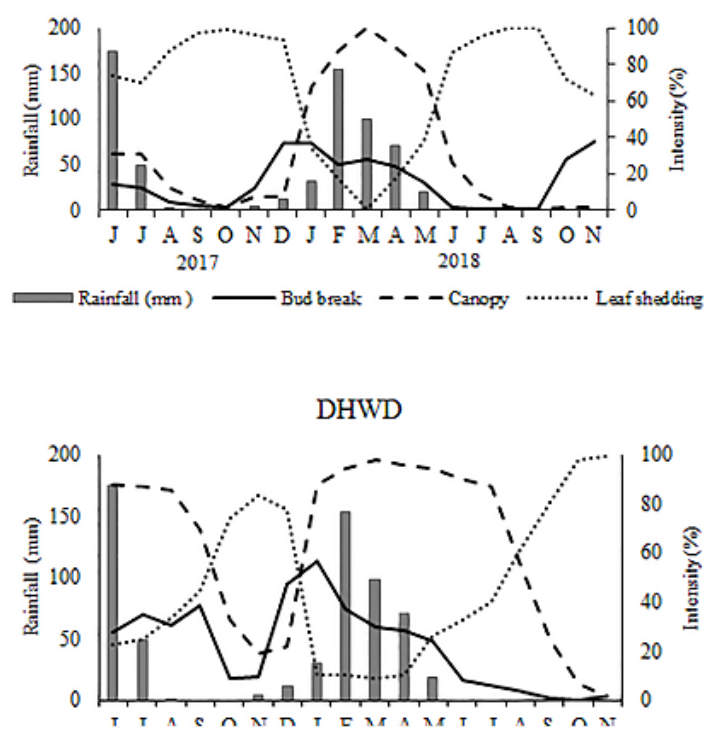

Figure 3

Vegetative phenological events of the functional groups identified in the riparian forest of Mata da Pimenteira State Park, Serra Talhada, Pernambuco, Brazil. DLWD: deciduous species with low wood density; DHWD: deciduous species with high wood density; SD: semideciduous species; EG: evergreen species. 


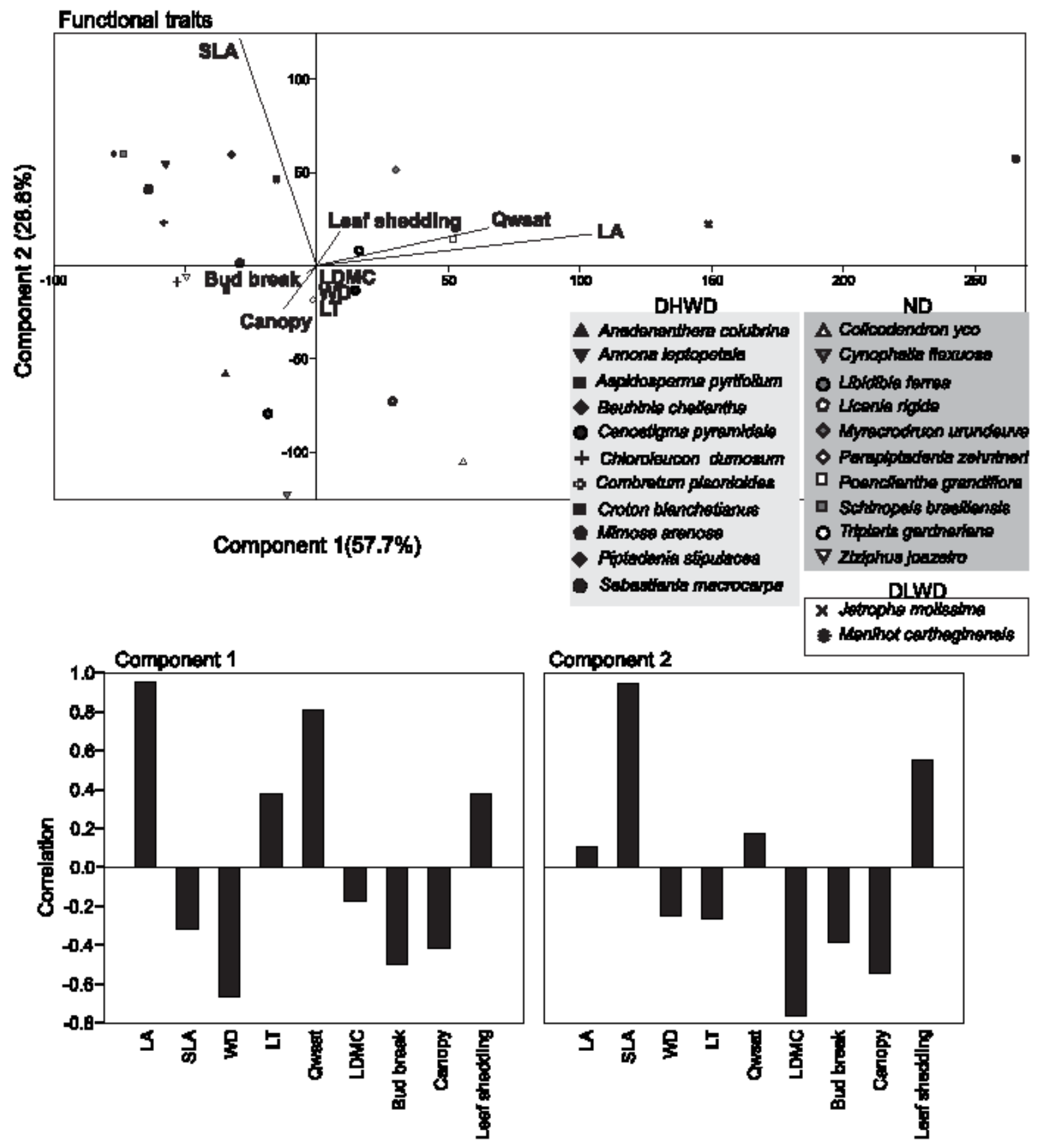

Figure 4

Principal Component Analysis (PCA) of the functional traits of the sampled species (LA = leaf area, SLA = specific leaf area, $\mathrm{WD}=$ wood density, LT = leaf thickness, Qwsat = amount of saturated water in the stem, LDMC = leaf dry matter content, DHWD = deciduous species with high wood density, DLWD = deciduous species with low wood density, ND = nondeciduous). 


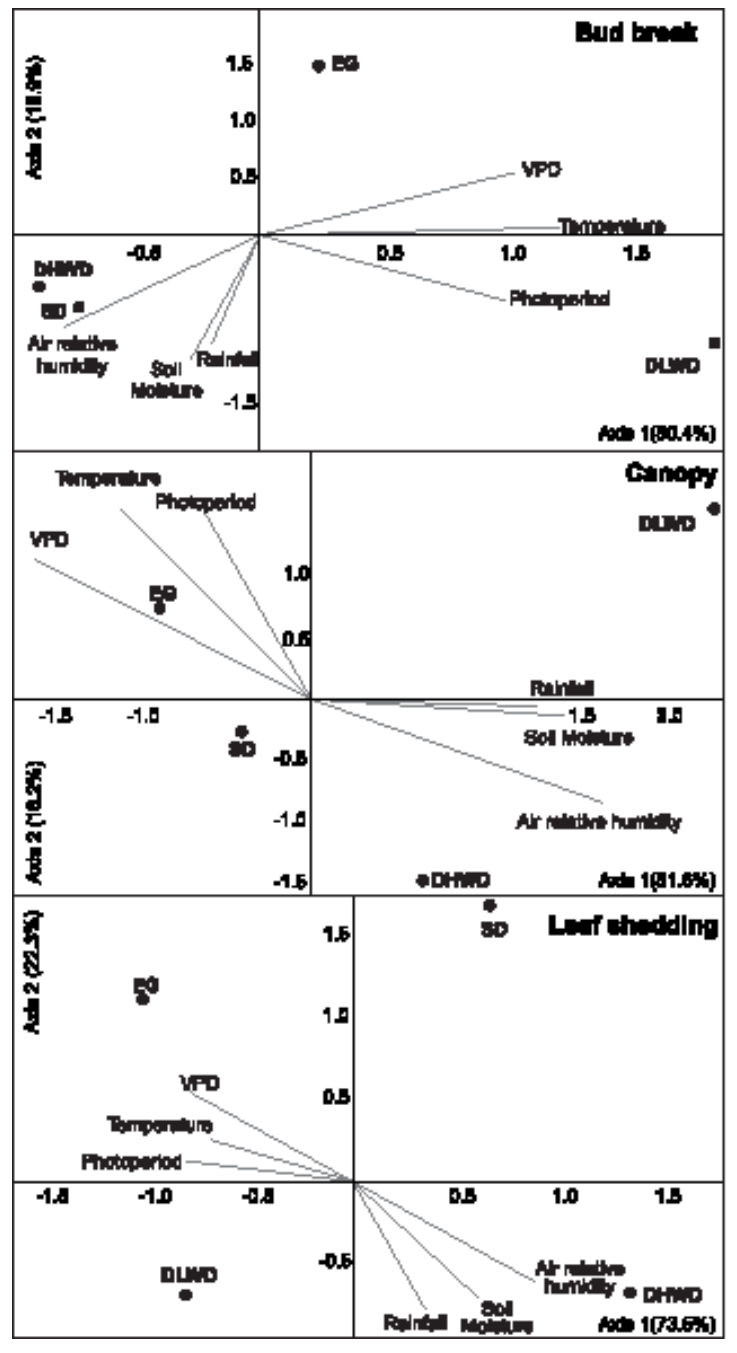

Figure 5

Canonical correspondence analysis (CCA) with environmental factors and functional groups for the vegetative phenophases of woody species from a riparian forest of Mata da Pimenteira State Park, Serra Talhada, PE, Brazil, from June/2017 to November/2018. 